\title{
A mise-en-scène do documentário: Eduardo Coutinho e João Moreira Salles
}

\author{
Fernão Pessoa Ramos'
}

1. Professor titular do Departamento de Cinema/Inst.de Artes/UNICAMP. Ex-presidente da Socine (1996/2000). Autor de A Imagem-Câmera (Papirus, 2012); Enciclopédia do Cinema Brasileiro (Ed. Senac, 2012); Mas Afinal, o que é mesmo documentário? (Ed. Senac, 2008); Cinema Marginal: a representação em seu limite (Brasiliense, 1987); Teoria Contemporânea do Cinema (Ed. Senac 2004). E-mail: ramos.fernao@terra.com.br 


\section{Resumo}

Neste ensaio abordaremos dois documentários recentes dos diretores brasileiros João Moreira Salles (Santiago) e Eduardo Coutinho (Jogo de cena). Buscamos desenvolver uma análise inspirada na metodologia fenomenológica, colocando ênfase na relação entre o sujeito que sustenta a câmera na tomada (sujeito-da-câmera) e o mundo que a ele se oferece, abrindo-se, pelo seu corpo, ao espectador. Denominamos de encenação essa relação entre o mundo (com pessoas agindo e coisas) e o sujeito que encarna a máquina-câmera. A mise-en-scène designa o modo pelo qual a encenação é disposta na tomada, levando-se em conta os diversos aspectos materiais que compõem a cena e sua futura disposição narrativa (em planos). Olhando para a história do documentário, podemos notar duas variantes estruturais na ação das pessoas para o sujeito-dacâmera: 1) chamamos de encenação-construída a ação ou expressão que é preparada, de modo anterior, pelo sujeito-da-câmera; 2) chamamos de encenação-direta a ação para a câmera solta no mundo, sem uma flexibilização direta pelo sujeito-da-câmera. No caso de um primeiro plano de encenação-direta, a indeterminação da ação é a própria fisionomia, conformando-se em afeto ou afecção. Em Jogo de cena estão dispostas diversas modalidades de encenação que interagem entre si, articulando-se em um corte desconstrutivo. Em Santiago, duas modalidades históricas do encenar contrapõem-se, num movimento animado pela má-consciência.

\section{Palavras-chave}

cinema, documentário, encenação, Eduardo Coutinho, João Moreira Salles 


\section{Abstract}

In this essay we will examine two recent documentaries by Brazilian directors João Moreira Salles (Santiago) and Eduardo Coutinho (Jogo de Cena). The analysis of the films will draw upon phenomenological methodology, emphasizing the relationship between the subject holding the camera in the take and the world that reveals itself to him, which opens itself through his body (subject-of-the-camera) to the spectator. We use the term staging (reenactment) to describe this relationship between the world (which includes objects and people in motion) and the subject which embodies the camera machine. Mise-en-scène denotes the way staging is set in the take, including the material aspects that comprise the scene and its future narrative arrangement (in shots). Looking at the history of documentary film, we can see two structural variants of action in the take to the subject-of-the-camera. We will call constructed stagingany action or expression that has been prepared by the cameraman beforehand. The free action occurring in front of a camera, without direct involvement or direction from the subject-of-the-camera, will be called direct staging. In the case of a closeup through direct staging the uncertainty of the action is the physiognomy in itself, which figures affect or affection. In Jogo de Cena, Coutinho uses a variety of staging techniques which are combined in a deconstructivist way. In Santiago, Salles contrasts two historical types of staging in a movement driven by remorse.

\section{Keywords}


O conceito de mise-en-scène possui ampla bibliografia no cinema de ficção, mas ocupa espaço paralelo na teoria do documentário. De origem francesa, o termo aparece nos escritos sobre cinema a partir dos anos 1950, tentando circunscrever a especificidade cinematográfica. As definições do que é mise-enscène variam ao longo da história. Recentemente, dois livros sobre o tema foram escritos por figuras centrais do pensamento em cinema: Jacques Aumont (2006) e David Bordwell (2005). Encontramos em Aumont um amplo retrospecto da evolução da mise-en-scène na história do cinema, recuperando o pensamento francofônico sobre o assunto. Bordwell segue trilha própria, privilegiando o leque conceitual do termo para avançar a análise sobre o espaço fílmico.

O conceito de mise-en-scène deve muito ao olhar de André Bazin, mas desemboca em seu sentido contemporâneo através da geração Nouvelle Vague, quando ela ainda exercia crítica de cinema (os hitchcocko-hawksianos), e dos cinéfilos chamados macmahonianos (Michel Mourlet, Pierre Rissient, Jacques Lourcelles). São eles que abrem os olhos de espectadores iniciados para uma visão estilística do cinema que vai além da elegia do "cinema puro" das vanguardas dos anos 1920 ou da montagem construtivista soviética. A noção de mise-en-scène pode ser entendida de modo amplo, mas um ponto deve ser realçado: os procedimentos de montagem, que definiram a essência da nova ar te na primeira metade do século XX, encontram-se, agora, em segundo plano. No universo valorizado pela mise-en-scène (a constituição cênica espacial), o movimento e a expressão dos corpos em cena têm destaque. Em um livrochave para esse debate, Sur un Art Ignoré, Michel Mourlet (2008) descreve a mise-en-scène enquanto "mise-en-place" de "atores e objetos em seus deslocamentos no interior do quadro", frisando que a distribuição plástica/ espacial de seres e de coisas deve "exprimir tudo". Para Mourlet, o âmago 
ano I número |

dossiê

da mise-en-scène está nas "atitudes e reflexos corporais dos atores", ou, em outras palavras, "na sintonia de um gesto com seu espaço". Se esse é o âmago da mise-en-scène no cinema, qual seria o campo da cena no documentário? Vejamos, mais de perto, como abordar essa questão.

No coração da encenação cinematográfica estão a noção de ação de um corpo e o que caracteriza essa ação em cena: seu movimento e sua expressão. A ação, na forma da imagem-câmera, é trabalhada dentro do quadro composto pelo molde da máquina que chamamos câmera. Se o primeiro elemento a chamar a atenção nesse "molde" imagético é a forma perspectiva, o que lhe dá absoluta singularidade no universo das imagens é a circunstância da tomada. A encenação cinematográfica é inteiramente determinada pela dimensão da tomada da imagem, em seu modo particular de lançar-se, pela circunstância do transcorrer, para a fruição do espectador. Ao afirmarmos que a cena fílmica é composta primordialmente pela ação na tomada, abordamos a noção de miseen-scène em sua veia mais profícua. A questão que se coloca é: no que a imagem, pelo fato de ser mediada pela câmera, transfigura a ação que transcorre na cena? Responder a isso significa realçar a camada do estilo cinematográfico propriamente, localizando elementos essenciais que definem a encenação em seu núcleo - a começar pela dimensão particular do espaço que, quando figurado em imagem-câmera, interage de dentro para fora do campo, e de fora do campo para dentro da cena. Ao centrarmos a noção de mise-en-scène nos parâmetros imagético-sonoros delimitados pela fôrma da máquina-câmera (falamos em uma cena-câmera), é necessário enfatizar o corpo em vida, a carne viva, que encarna necessariamente a ação cênica, constituindo o coração da encenação cinematográfica no tempo presente. Mencionamos os elementos de estilo que emolduram a ação: a fotografia, o figurino, o cenário, o estúdio, a locação, o enquadramento, a movimentação da câmera, a profundidade do campo cênico, o espaço fora de campo, a decupagem da ação. Mas podemos ir além e definir a especificidade da cena fílmica/documentária na lide com o 
sujeito (pessoa ou ator) que vive, enquanto sustenta a ação na tomada presente: espécie de carimbo de sua fisionomia e de seus gestos que o rosto e a expressão dos afetos evidencia, conformando a encenação propriamente.

\section{A tomada e o sujeito-da-câmera}

A imagem-câmera fílmica tem por característica ser constituída ao se conformar em um tipo de figuração do mundo que chamamos tomada. A tomada estrutura um movimento de figuração que é singular à imagem-câmera e que outras imagens não possuem: é composta pela ação do corpo em movimento e por sua expressão. Definiremos como "expressão" a figuração de afetos pelo ator/personalidade que age na circunstância da tomada. A expressão é significada pelo corpo por meio do olhar, da composição fisionômica e dos gestos. A “ação" é movimento no mundo. Ação e expressão constituem o núcleo dos procedimentos que caracterizam a encenação fílmica e sua miseen-scène. É aí que bate o coração da cena cinematográfica e de sua narrativa. A ação do corpo na tomada e a expressão de seu afeto pela fisionomia e pelo gestual constituem o umbigo da especificidade da encenação documentária que se constela concretamente (se afigura) no tempo presente, no transcorrer do presente enquanto franja de um acontecer. É nas especificidades do movimento e da expressão do corpo em cena, nas diversas modalidades de interação com o sujeito que sustenta a câmera, que recortaremos o conceito de mise-en-scène para articulá-lo ao campo documentário. É na ação do corpo em cena, do corposujeito da tomada (para e pela câmera, lançando-se, enquanto imagem futura, ao espectador e sendo por ele determinado), que iremos atingir o coração da mise-en-scène para fazê-lo pulsar dentro da estilística documentária.² 
Estamos nos referindo ao modo pelo qual o corpo do ator, ou da pessoa/ personagem, encarna a ação e ocupa o espaço na forma de argumento documentário (ou expressão lírica documentária). A figuração do corpo pela ação fílmica constitui, em seu âmago, a noção de mise-en-scène. O estilo é o movimento/expressão com o qual o corpo encarna ação e afeto. Essa "encarnação" interage ativamente com a dimensão presencial do(s) sujeito(s) que sustenta(m) a câmera no mundo, na situação de tomada, e que, em geral, está fora do campo da cena que a tomada constrói. O corpo que encena encena para alguém. Encena para um espectador futuro (e essa dimensão ancora a tomada), mas também para um sujeito que o encara face a face, um sujeito que chamarei de sujeito-da--câmera.O sujeito-da-câmera tem corpo e está vivo. O sujeito-da-câmera surge transfigurado pela máquina-câmera que o abriga junto de si, incorporado a seu modo de ser para o mundo e para o ator/pessoa. O sujeito-da-câmera funciona como a boca de um funil que, ao fundar a tomada, puxa o mundo para o espectador ao ser determinado por sua presença futura. A presença do sujeito-da-câmera funda a tomada, ao transformar ação em encenação. Não se constitui propriamente em indivíduo físico, mas incorpora a máquina que sustenta no cor po e também a equipe que o faz existir como imagem cinematográfica. O sujeito-da-câmera é a máquina, mas também tem corpo, e é com esse corpo (ou esses corpos) que a ação, transformada em encenação, vai interagir. O sujeito-da-câmera tem carne e vive no presente. A tomada que ele funda transcorre. O sujeito-da-câmera estampa, ao se oferecer na tomada, além de si mesmo, o espectador. O espectador vem pintado em sua face e exala de seu corpo. $\mathrm{O}$ ator/personagem da tomada, ao olhar para o sujeito-da-câmera, vê a expressão da figura que dirige suas ações, mas vê também, sobreposto nele, o espectador. O espectador está lá, bem grande no olho humano do sujeito-dacâmera e no olho mecânico da câmera. A tomada, com seus corpos e objetos, lança-se para o espectador e é inteiramente determinada por esse lançamento. 
Já o espectador lança-se para a circunstância da tomada em um movimento cuja descrição escapa ao âmbito deste artigo. A imagem-câmera traz em si o mundo da tomada e o faz transparecer de um modo que outras imagens (como a imagem pictórica) não fazem. A imagem-câmera é transparente e o espectador vê o mundo da tomada através dela, na forma que se afigura. O sujeito-dacâmera faz valer a figuração do mundo na tomada, medindo (compondo) sua forma para a fruição espectatorial futura. A dimensão da fruição futura pesa na tomada e determina procedimentos diversos de encenação. A singularidade da imagem-câmera, da imagem do cinema, está na dimensão da tomada e no movimento de "lançar-se para" que sua mise-en-scène instaura.

\section{As personagens e a encenação}

O corpo do ator, ou da pessoa, carrega uma camada de densidade psíquica que chamamos "personalidade". Conforme a densidade aumenta na atuação face à câmera, a camada da personalidade condensa-se, destaca-se, e afirma-se em personagem. O cinema documentário contemporâneo possui particular atração pela camada de gordura da atuação que exala do corpo exibindo-se, mostrandose, para o sujeito-da-câmera. Descobrir uma personalidade fotogênica significa encontrar uma personagem que saiba interagir com a circunstância da tomada e sustentar o afeto por meio do olhar lançado, pela câmera, para o espectador; alguém que possua uma história de vida que embase esse olhar pela fala e pelos gestos, dando corpo à trama ou à enunciação assertiva. Densa de personalidade, a personagem move-se, age, atravessa a cena fílmica. O outro corpo (aquele que sustenta a câmera e está atrás dela) irá comutar criativamente sua expressão de sujeito da câmera pela expressão do corpo/personagem que encena à sua frente, encarnando uma personalidade. Personalidade que não é a da sua pessoa em si, nem existe somente para o sujeito-da-câmera: é a de uma personagem que surge na tomada, transfigurada pela alquimia da representação que envolve a 
máquina-câmera, enquanto é lançada para o espectador. A esta comutação, no cinema de ficção, chamamos direção de atores.

No caso do documentário (pelo menos desde Nanook, o esquimó), a personalidade que o olhar, pela alquimia da fotogenia, exala para o sujeito-dacâmera, faz parte integrante da criação autoral. Seja dentro de uma direção mais incisiva, seja por meio da presença recuada do diretor, seja pela simpatia sutil de um sorriso, ou de um levantar de sobrancelha, a direção de cena voltada para a figuração da personalidade percorre a história do documentário.

O olhar (o olho do corpo, propriamente) marca uma forma expressiva recorrente na estilística cinematográfica. Ao pensarmos a mise-en-scène enquanto forma cinematográfica do movimento de corpos em cena devemos estabelecer a distinção, extrema, entre o ser que sustenta uma personagem numa trama construída para ser encarnada e o ser que ordinariamente está no mundo, propondo-se ocasionalmente agir para a câmera. Como expressar, no cinema documentário, a "encarnação" de uma personagem? No caso da ficção, temos um termo bem preciso para descrever essa operação: trata-se do trabalho daquele que chamamos ator, ao qual damos o nome de "inter pretação". O documentário, no entanto, pouco trabalha com atores profissionais. Nunca desenvolveu um estilo, ou uma produção mais ampla, para aproveitar seu trabalho. A tradição documentária nunca sentiu necessidade de um starsystem. Por outro lado, no documentário, o corpo, dotado de personalidade, composto em personagem, não é um corpo qualquer, em seu modo de ser espontâneo no mundo. A densidade estilística da encenação documentária distingue-se facilmente da imagem-qualquer de câmeras de segurança. A diferença está no corpo denso do sujeito-da-câmera, existindo através de 'si', câmera, para o mundo e para a personagem. A diferença está na comutação entre esse 'si' do sujeito-da-câmera e a ação do corpo que se oferece para o espectador futuro, através do 'si' da câmera. 
O documentário trabalha bastante com atores naturais, pessoas comuns, que não são profissionais em expressar personalidades outras que si próprio. A presença da câmera, no entanto, pode transtornar seu jeito (e sua personalidade) de ser no mundo, constituindo uma primeira modalidade de atuação: eu sou eu mesmo em face do sujeito que sustenta a câmera, mas sua presença me transtorna, transtorna alguns traços da expressão de meus afetos, e eu viro personagem. Chamarei este tipo de atuação de encenação-direta. No entanto, enquanto pessoa no mundo, também posso ser convidada a incorporar a personalidade de um amigo, de um vizinho ou de um desconhecido. Apesar de não ser ator, conheço o universo da personalidade que devo interpretar e aceito a proposta. Chamarei este outro tipo de encenação, bastante comum na história do documentário (cito o exemplo do trio "familiar" de O homem de Aran, ou os "carteiros” de Night Mail), de encenação-construída.

Para pensarmos a cena documentária deveremos ampliar semanticamente a noção de "cena", fazendo-a caber em estruturas que nem sempre foram caracterizadas como próximas do conceito de mise-en-scène. A cena composta por cenário, figurinos e estúdio compõe uma parcela considerável da tradição documentária, mas não está localizada, por assim dizer, no centro de sua estilística, como ocorre no cinema de ficção. Devemos reconhecer que a exuberância estilística da mise-en-scène do cinema de ficção não é repetida na tradição documentária, constituindo-se a partir de outras variáveis. Ao pensarmos a encenação documentária em seu núcleo criativo, nos deparamos com a movimentação do corpo na cena da tomada (sendo designada por este termo a circunstância da presença da câmera, e do sujeito que a sustenta, no mundo e na vida). O documentário é a forma narrativa privilegiada da tomada, no presente. É sob a forma de uma presença que a tomada cinematográfica consegue fincar seu gancho no transcorrer e abri-lo, como abrimos a uma 
ano I número |

dossiê

lata, constituindo, na dilatação da abertura, o corte narrativo. ${ }^{3}$ Nela caminha a estilística da encenação documentária, em seus diferentes formatos históricos. Quando a encenação na tomada é explorada estilisticamente em sua radical indeterminação, liga-se umbilicalmente ao transcorrer do mundo no presente, em sua tensão de futuro ambíguo e indeterminado. A ação que explora a circunstância indeterminada da tomada ocorre sob a forma da encenaçãodireta, ou da encena-ação/afecção. Quando a encenação documentária for refratária à indeterminação do tempo presente na tomada, quando trabalhar, por exemplo, com a encenação em estúdios, decupada em planos prévios por roteiro, a chamaremos de encenação-construída. Os dois tipos de mise-en-scène documentária, a encenação-direta e a encenação-construída, constituem as formas privilegiadas da estilística narrativa documentária, com modalidades intermediárias diversas. Conforme o sujeito-da-câmera relaciona-se com o que lhe é exterior - o mundo da tomada - constela-se um tipo narrativo documentário que traz em si uma forma de encenação, isto é, uma forma determinada de estar no mundo para o sujeito-da-câmera, lançando-se para o espectador.

Podemos localizar esses tipos gerais, sem muito esforço, na tradição documentária. No chamado documentário clássico, anterior aos anos 1960, e no documentário contemporâneo, exibido em redes de televisão a cabo, predomina a encenação-construída. No documentário chamado de direto ou verdade, em sua vertente moderna, temos a predominância da encenação-direta, aberta à indeterminação do transcorrer, em interação à qual constrói seu estilo. Estas são determinantes estruturais amplas, que devem servir apenas para nos situar numa totalidade plena de nuanças. As duas formas de encenação na tomada interagem entre si e não são excludentes (pelo contrário). Se sua eclosão pode ser determinada historicamente, elas estão longe de ser estáticas ou se restringir a um período de tempo. O importante está em reconhecermos sua validade

3. Interessante abordagem da relação entre narrativa e acontecer encontramos em Tempo e narrativa, de Paul Ricoeur (Campinas, SP: Papirus, 1994). 
estrutural para, a partir daí, sofisticarmos a análise. Em outras palavras, se falamos de uma mise-en-scène documentária, colocando em seu centro a relação entre sujeito-da-câmera e mundo na tomada, é necessário pensar essa mise-en-scène em sua disposição histórica, no decorrer dos séculos XX e XXI.

\section{A encenação-direta}

Para fazermos esse percurso é importante desvincularmos o conceito de encenação de sua carga semântica tradicional. Não se trata de querer desconstruir a intensidade da tomada para mostrar que por trás da espontaneidade existe construção, existe "encenação". A encenação documentária, em sua tendência moderna, que emerge nos anos 1960, encobre um tipo de agir que é na tomada em similaridade ao que nós somos no mundo. Mas nós não encenamos em nosso mundo cotidiano, como um ator encena no palco de um teatro. Nós não encenamos pelo espectador, para a câmera. Nós somos, no mundo, segundo a circunstância, em adequação ao que consideramos a essência da personalidade de nosso ser e a demanda do mundo sobre ele. Isso seria também encenação? Se enceno o professor quando dou aula, se enceno o pai quando estou com meu filho, se enceno o chefe quando distribuo tarefas, o conceito de encenação amplia seu horizonte e confundese com estar no mundo. O tipo de ação que se desenrola livre no transcorrer indeterminado da tomada é próprio a um estilo cinematográfico que embasa uma forma narrativa e que estamos chamando de "direto". Estou, portanto, definindo um tipo de ação para a câmera como encenação-direta, sugerindo que podemos decompô-la em encena-ação e encena-afecção.

Em suas diferentes formas estilísticas, a encenação-direta pode ser composta pelo sujeito-da-câmera, mais recuado ou mais ativo (intervindo no mundo ou voltando-se sobre as próprias condições de enunciação). A encena-ação direta é uma encenação que não se constrói de modo prévio e decupado, diferente da 
ano I número |

dossiê

interpretação do ator. A encena-ação é a ação, é a intervenção que transcorre no mundo, significa movimento e, mais do que isso, embate, interação ativa com seres e coisas que compõem a circunstância da tomada e, em particular, o sujeito-da-câmera. Significa também movimento livre, pelo sujeito-da-câmera, para o espectador. É para isto que estamos na tomada. Mas, na encenaçãodireta, a flexão da ação pela presença da câmera é tênue. O segredo do cinema direto, no final dos anos 1950, foi ter percebido que a inflexão tênue da ação para a câmera poderia resvalar na imagem-qualquer obtida com uma câmera oculta, mas nunca coincidir. O charme foi haver descoberto que a encenação para câmera rendia arte, que as imagens resultantes (mesmo com o recuo do sujeito-da-câmera) eram intensas e cheias de poesia. Pessoas transformavam-se facilmente em personagens, flexionadas pela presença do sujeito-da-câmera, cuja carne presente dava espessura à vida ordinária numa espécie de "mundanidade" ordinária. Por outro lado, o transcorrer da tomada poderia ser explorado propriamente como um acontecer, na intensidade de sua radical indeterminação e ambiguidade. O presente transcorrendo podia acontecer na forma da ação repleta de intensidade da História. Robert Drew almejava captar estes momentos de modo sistemático (através da "crisis structure"), mas acabou desistindo de trabalhar com a encenação-direta da História, carregada de intensidade. Descobriu que filmar a História exigiria, no limite, a provocação do próprio momento histórico, numa complexidade infinita de variáveis a serem articuladas. A partir do momento em que se deixa de ter como referência a encenação-construída clássica, encontra-se com uma articulação cênica (pois é disto que se trata) desconhecida. Na fronteira entre a indeterminação ontológica da ação intensa e a estruturação que demanda o sujeito-da-câmera para a encenação-direta, a ação da História não poderia ser encenada para a câmera no formato narrativo que o primeiro cinema direto necessita. Não era só o espetáculo que buscavam, mas uma espécie de narrativa (cinematográfica) incrustada no transcorrer da História, na franja do presente. Mais tarde, no decorrer dos anos 1970, essa equação 
do eclodir da ação intensa e da História é resolvida com facilidade com uma postura mais ativa do sujeito-da-câmera, sem medo de figurar-se como agente transformador (Harlan County, de Barbara Kopple, 1976).

Já a encena-afecção envolve menos ação e mais expressão. Envolve a figuração do afeto, e da personalidade, pelo corpo. E o corpo do sujeito no mundo exprime afeto principalmente pelos traços fisionômicos da face e pelos gestos (movimentos dos membros do corpo). O cinema direto, historicamente, voltou-se, desde o início, para os primeiros planos. A encena-afecção aparece nos rostos em primeiro plano, é o estilo voltado para a fisionomia e o afeto que expressa, para os gestos imperceptíveis (a mão de Jacqueline Onassis atrás das costas, em Primary), para a suspensão da ação e do argumento, no intervalo da expressão que se dilata (Maysles). A encenação documentária também mostra o corpo na tomada asserindo, falando sobre si ou sobre o mundo. A fala é parte integrante do ser no mundo e a encenação direta toma outra dimensão quando, tecnologicamente, a captação da fala no mundo torna-se possível. É importante notar que o modo documentário de asserir sobre o mundo é modulado pelo corpo falante. A descoberta das potencialidades da entrevista/depoimento, do corpo que fala para enunciar, caminha nessa direção. A articulação narrativa do documentário direto, enquanto unidade fílmica, tem como matéria-prima, para compor seus argumentos, o corpo que fala. A voz, na forma articulada da fala, é um dos elementos essenciais do ser no mundo para a câmera e é elemento capital para a própria articulação narrativa documentária, por meio da composição de enunciados assertivos.

\section{A encenação-construída}

A encenação-construída está no coração da composição estética do documentário, trazendo consigo métodos que percorrem a primeira metade de século e se estendem até o presente. Na contemporaneidade, 
ano I número I

dossiê

a encenação-construída é bastante utilizada na mídia televisiva. Em sua forma narrativa documentária, teve seu principal núcleo teórico na escola documentarista inglesa, em geral identificada na figura de John Grierson, seguido de perto por Paul Rotha. Tanto Grierson como Rotha escreveram extensamente sobre a práxis documentária, fixando formas e justificativas para sua inter venção no mundo, e determinaram uma ética documentária, orientando os objetivos e os valores do fazer documentário com regras bastante claras. A presença da voz over é um elemento estrutural da encenação-construída do documentário clássico da primeira metade do século. Não é avaliada de modo negativo, como no pensamento moderno. No documentário clássico contemporâneo, a encenação-construída é comumente misturada à utilização de entrevistas ou depoimentos (em geral no modo de encenação-direta). Também imagens de arquivos costumam estar presentes, embora envolvam tipos de encenação para a câmera que se distinguem da encenação-construída. A encenação-construída tem facilidade de ser desenvolvida na presença da voz over, pois determina um tipo de encenação facilmente desvinculado do contexto de mundo que cerca a circunstância do transcorrer da tomada. A voz over na encenação-construída pode ser definida como uma fala sem corpo. Acompanha e ilustra a ação que é reconstruída na tomada. Ação que reconstrói a circunstância que anteriormente lhe deu origem e que está sendo representada.

A encenação-construída pode, por exemplo, recompor eventos históricos por meio de diálogos encenados, muitas vezes confundindo-se com a forma dramática de representar de um filme de ficção. No entanto, o modo dramático não costuma dominar o documentário clássico como um todo, sendo intercalado com depoimentos, entrevistas, material de arquivo etc. A encenação-construída conforma a ação dos agentes para enunciar argumentos através de procedimentos que alguns críticos excluem da tradição documentária. A construção do espaço envolve a utilização de cenários e estúdios feitos especialmente para a encenação do filme. A 
encenação-construída pode também ocorrer em locações que não envolvem estúdios, sendo provavelmente o modo predominante nos documentários. A encenação-construída documentária não costuma ser encarnada por atores profissionais, sendo conduzida por atores amadores ou por pessoas que vivem próximas ao universo representado (os pescadores de O homem de Aran; os inuítes de Nanook; os funcionários do correio britânico de Night Mail).

A fotografia para iluminar a encenação-construída no modo clássico pode ser bastante sofisticada. É preparada com grande antecedência e previsibilidade em cada plano decupado. Sobredetermina a marcação da cena e a movimentação dos corpos. A tomada propriamente é planejada por um roteiro que detalha a decomposição plano a plano e a distribuição da ação no espaço cênico. A decupagem das tomadas é submetida e determinada pela futura edição. Alberto Cavalcanti, em seu manual de documentário Filme e realidade, numa explanação já tardia das máximas do classicismo documentário, detalha os procedimentos necessários para o planejamento, central na formação de um bom documentarista: "não negligencie o seu argumento, nem conte com a chance durante a filmagem: quando o seu argumento está pronto, seu filme está feito; ao iniciar a sua filmagem você apenas o recomeça novamente" (CAVALCANTI, 1957, p. 81). A encenação-construída no documentário trabalha a tomada por meio da preparação prévia e sistemática da cena, envolvendo nesse planejamento as falas, a movimentação dos corpos e da câmera, a fotografia, a cenografia, o roteiro, a decupagem. Enquanto a encenação-direta cavalga na indeterminação do transcorrer, explorando-o como forma de estilo, a encenação-construída age no modo fechado da previsibilidade, dentro de unidades "plano" que a composição narrativa demanda previamente de modo mais rígido. O corpo que encarna a ação construída na tomada não age em si: expressa-se para a câmera, mas dentro de modalidades de ações antevistas que lhe são determinadas a priori, a partir de traços já levantados da personalidade de outrem (o filho do pescador, a mãe do pescador, o funcionário aplicado do correio, Cleópatra, Getúlio Vargas). 
O grau de fechamento na preparação prévia da ação varia de acordo com ano I número | os preceitos estilísticos dominantes em cada época ou estilo. O importante é frisar que, na encenação-construída, é bastante estreita a abertura da ação, na tomada, para a indeterminação. A encenação clássica não reconhece (não explora) a ambiguidade na extensão temporal da tomada. Também a composição dos afetos na face do corpo não surge em destaque, pois a configuração progressiva da fisionomia é um movimento (o movimento dos traços fisionômicos) pleno de indeterminação. A intensidade da imagem que a indeterminação produz na tomada é explorada de modo esporádico, não se constituindo em polo da composição narrativa. É o caso emblemático de Flaherty. Existe uma cobrança de que Flaherty tivesse trabalhado, já nos anos 1920, na modalidade direta de encenação. Esquece-se que esse modo de encenar para a câmera, historicamente, surge apenas no final dos anos 1950. A reflexão contemporânea tem claras dificuldades em lidar com a arte da encenação- construída no documentário. A tabela de valores éticos dominante é modelada por expectativas de um tipo de encenação marcada pela postura reflexiva. Ficam faltando ferramentas para uma avaliação precisa dos procedimentos de construção da encenação que têm corte mais clássico.

Reconstituições com intenso uso de tecnologia digital, mas baseadas em encenações com bonecos, do tipo Walking with Dinossaurs ou Walking with Beasts (BBC), também são formas de documentário com uso intensivo de encenações construídas para a câmera. As imagens são tomadas em encenações planejadas para explorar o espaço dentro de campo (espaço in) em sua radical heterogeneidade com o espaço fora de campo (espaço off). Na sequência das tomadas com encenação-construída, as ações encenadas e seu espaço sofrem uma radical manipulação digital até adquirirem a forma desejada. A manipulação digital de imagens originárias de tomadas é hoje corriqueira no documentário. Podem também ser encontradas em torno de encenações obtidas no modo direto, inclusive na primeira pessoa (encenação de 'si', como 'eu' para 
um sujeito-da-câmera que pode, inclusive, ser 'si' próprio). Tarnation (2003), de Jonathan Caouette, é um documentário construído com farto material de tomadas em primeira pessoa ou filmes de família (nesse caso, o sujeito-dacâmera faz parte da vida pessoal de quem está encenando para ele no modo da encenação-direta). Parcela significativa do material de arquivo (tomadas mais antigas, heterogêneas às tomadas atuais para o filme) sofre manipulação digital nas bordas ou no âmago do quadro. As figuras que compõem a matéria desse quadro (o plano propriamente) são distorcidas, mantendo-se, no entanto, o caráter indicial que as liga à circunstância da tomada. É importante frisar a diferença dessas imagens para com imagens animadas (gráficos ou imagens figurativas em movimento), obtidas inteiramente por meio de animação, ou manipulação digital interna ao computador (sem utilização de câmera). A manipulação da imagem de tomada (a imagem-câmera), em geral, não lhe retira a potencialidade de transparecer a circunstância da tomada. Por detrás da manipulação digital permanece a carne do mundo, que teve presença no presente na tomada. É para essa circunstância que se lança o espectador.

Em Ryan (2004), de Chris Landreth, a espessura da manipulação digital é densa, mas o filme respira encenação-direta para a câmera, impedindo que o caracterizemos como mero filme de animação. A composição dos traços na imagem filmada é talentosa, levada adiante por um ar tista de destaque no cinema de animação filmando a vida de outro grande talento no gênero, Ryan Larkin. Landreth percebe a força que possui a encenação de Larkin nos depoimentos e consegue mantê-la intacta na tensão da tomada, inclusive nas entrevistas com próximos e familiares. Em Ryan, por trás da manipulação digital, vemos transparecer a tomada e o mundo da circunstância da tomada que a câmera originalmente constituiu, com sua fôrma de traços reflexos e perspectivos. O filme permite ao espectador que se lance para lá, apesar da densidade da manipulação digital dos traços, distorcidos com técnicas sofisticadas de animação. A relação entre animação e documentário está na raiz da tradição 
documentarista, já presente em diversos trabalhos do documentarismo clássico britânico, depois caracterizando dois polos de atuação do National Film Board.

Outro filme que explora bem esse limite é Valsa com Bashir (2008), de Ari Folman. Folman encena inicialmente no modo construído, utilizando entrevistas e depoimentos, dentro da característica narrativa documentária clássica. A decupagem da ação é feita previamente, prevista em detalhes e encenada inclusive em estúdio, para servir de matéria à animação. Folman poderia ter feito um filme documentário com essas tomadas, encenadas no modo construído e intercaladas com depoimentos e entrevistas. Preferiu, no entanto, desenhá-las e animá-las a posteriori, quadro a quadro, no que parece ter sido um trabalho insano. Folman desenhou as imagens tendo como matéria originária (embora não exclusivamente) imagens-câmera que já havia filmado com encenação-construída em estúdio, além de entrevistas. O documentário é forte e, apesar da encenação-construída manipulada para servir ao trabalho de animação, mantém a intensidade característica das imagens-câmera. Ao final, no entanto, Folman não resiste à força da memória. Seu inconsciente (pois é um filme que narra o trauma na primeira pessoa) parece vir à tona com força e a ruptura própria à representação intensa se instaura. Ele precisa da imagem direta para representar o trauma que dá origem ao filme e fazer brotar a intensidade que a representação do impacto pede. O trauma, conforme vivido por seus olhos de adolescente, deve ter a representação que lhe cabe e que só pode ser a da imagem com encenação-direta para a câmera. As imagens-câmera do massacre de Sabra e Chatila, no Líbano, em 1982, com os cadáveres e os gritos lancinantes de desespero para o sujeitoda-camêra, conforme esse sujeito havia estado lá, visto e ouvido a barbárie e a tragédia. A ação é então exibida, no final do filme, no grau máximo de intensidade, sem manipulação digital nem procedimentos de animação. As imagens compõem, em sua definição literal, o que Barthes um dia chamou de "imagem traumática" (tema que Bill Nichols articula sob o conceito de 
"magnitude"). No ensaio "Inscrevendo o espaço ético: dez proposições sobre morte, representação e documentário", Vivian Sobchack (2004) nos descreve um dos tipos do olhar do sujeito-da-câmera diante da morte, na tomada, como um olhar "impotente". É a partir desse olhar, paradigma do cinema direto, que Sobchack irá construir a tipologia dos olhares no documentário (olhar “ameaçado”, “interventivo”, "humanitário”, "profissional”) que servirá de inspiração para a articulação da conhecida tabela dos modos documentários, conforme estabelecida por Nichols no início dos anos $1990 .{ }^{4}$

Na encenação-construída clássica, não está no horizonte voltar-se sobre o próprio ato, de modo a chamar a atenção do espectador sobre aquele que constrói a encenação de quem encena. Diretores de corte moderno que trabalham com esse tipo de encenação (como Peter Watkins, em documentários como Culloden, La Commune ou The War Game) desenvolvem procedimentos narrativos diversos que instauram dimensões reflexivas ou polifônicas no modo construído da ação. Um diretor como Vertov, que não trabalha com a encenaçãoconstruída, mas que está sintonizado avant la lettre com a demanda reflexiva, só consegue encontrar contexto para repercutir sua produção nos últimos anos da década de 1960 (sua redescoberta, na década de 1950, ainda não coloca ênfase no aspecto construtivo). Já a encenação-direta, uma vez dominante, traz facilmente os holofotes sobre o próprio encenar, a partir da sobreposição entre a personalidade exibida para a câmera e o corpo próprio do sujeito que encarna essa personalidade. Na contemporaneidade, principalmente a partir dos anos 1980, a encenação-direta abre-se para o corpo próprio de quem enuncia. Explora uma espécie de primeira pessoa da encenação, dramatizando a performance de sua vida, ou de sua opinião, face à câmera. A elocução autobiográfica consegue

\footnotetext{
4. Sob “magnitude”, ver Nichols (1991: 229-266). A versão definitiva dos modos aparece com suas seis variáveis em Introdução ao documentário (NICHOLS, 2005: 135-177). Sobre a questão intensidade/ética da imagem e a relação entre a tipologia de Nichols e o trabalho de Sobchack, escrevi "A cicatriz da tomada: documentário, ética e imagem intensa”. (in RAMOS, Fernão Pessoa [Org.]. Teoria contemporânea do cinema: documentário e narratividade ficcional. São Paulo: Ed. Senac, 2004).
} 
ano I número |

dossiê

então um espaço inédito na produção documentária. As asserções sobre temas sociais e políticos mais amplos são mediadas pela elocução ampliada da primeira pessoa, na qual ganham reverberação diferenciada. Por meio do corpo e da fala na primeira pessoa, essas asserções parecem adquirir espessura e pertinência que não mais obtêm quando enunciadas simplesmente na forma de proposições, faladas em voz over sobre o mundo.

O conceito de encenação, portanto, não pode ser visto de modo uniforme na história do documentário. Tudo se tornaria encenação, seja no documentário, seja na ficção. Não se pode colocar no mesmo patamar uma encenação em estúdio e uma leve inflexão de voz provocada pela presença da câmera. Os atos de encenação dos três habitantes de Aran que, sem nenhum vínculo de parentesco, interpretam uma família nuclear, surgiriam como equivalentes às atitudes "afetadas" de Edith e Edie Beale em Grey Gardens, ou de Luiz Inácio Lula da Silva em Entreatos (João Moreira Salles, 2004), ou ainda de Robert Kennedy em Primary (Robert Drew, 1960). Não podemos dizer que Lula, Kennedy ou Edie Beale encenam para a câmera como encena o pequeno garoto, que faz o filho que não é, em O homem de Aran. Lula, Kennedy e Edie encenam o que são em si mesmos. Certamente sua atitude é flexibilizada pela presença da câmera, que lhes deixa o espaço necessário para agir e exprimir suas personalidades na face e nos gestos. No caso de Kennedy e Lula, a fruição do espectador está em ver o corpo de duas personalidades públicas em sua expressão cotidiana. O filme de Salles, inclusive, se intitula Entreatos, ou seja, a ação, de cunho pessoal, entre os atos públicos. A personalidade densa de ambos (um mais retraído, Kennedy, outro bem mais expansivo, Lula), transparece para o espectador como presença do corpo próprio na circunstância da tomada. Já no caso de Edith e Edie Beale lidamos com personalidades anônimas que emergem em densidade transfiguradas pela presença da câmera. E essa densidade surge de modo tal que surpreende e comove. A personalidade transparece na imagem em primeiro plano 
(expressões e gestos) e na forma de se movimentar (ação). O gesto é ainda mais fascinante no contexto do início dos anos 1960, e compreende-se facilmente o impacto que filmes introduzindo esta forma de encenação provocaram.

A exploração do tipo de encenação-direta para a câmera não se restringe à forma narrativa documentária e amplos setores da mídia televisiva a utilizam, seja no jor nalismo, seja em for mato mais espetacular (como mostra o fascínio que exercem os programas de reality show). Figuras como Edie Beale, Paul Brennan (em Caixeiro viajante, de Maysles, 1968), Estamira (em Estamira, de Marcos Prado, 2005) e Santiago (em Santiago, de João Moreira Salles, 2007) compõem personagens que, na história do cinema, figuram como densos, equivalentes a criações ficcionais famosas. Certamente, nesse tipo de composição existe a transfiguração no mistério da fotogenia (ser esteticamente para a figuração imagética da máquina câmera), mas a construção do tipo personagem não deve ser reduzida a essa variável. Talvez Nanook (Allakariallak) tenha sido, historicamente, o primeiro dos grandes personagens de documentário feitos a partir de personalidades corriqueiras. O primeiro grande personagem que a encenação para a câmera promove. E é significativo que o formato narrativo documentário tenha se cristalizado justamente nesse momento, descobrindo como se configura uma personalidade anônima olhando para câmera. O olhar e a expressão de Allakariallak comovem até hoje e ele está lá, em seu ser, agindo para a máquina-câmera, na força que as imagens do filme mantêm através das décadas. A força de seu olhar, de sua expressão, consegue perfurar o modo construído da encenação do documentário clássico para se misturar à maneira de agir em si próprio, para a câmera. A mistura é estranha e contraditória e o filme extrai daí seu estatuto de clássico. 


\section{Salles e Coutinho}

João Moreira Salles e Eduardo Coutinho trabalharam, em seus últimos filmes, numa mesma produtora cinematog ráfica (Videofilmes), de propriedade de Salles. Este último produziu os longas recentes de Coutinho, com influência, mesmo se não creditada, na constituição das obras e em sua edição final. Coutinho, de uma geração mais velha, é considerado por alguns como o principal documentarista latino-americano da atualidade. Salles - que vem de família de banqueiros, irmão de um cineasta mais conhecido, Walter Salles -, resolveu seguir carreira independente no cinema documentário, assinando obras de repercussão como Notícias de uma guerra particular (1998) ou Nelson Freire (2002).

Santiago (2007) é um filme em que o diretor João Moreira Salles voltase sobre tomadas, feitas em 1992, de um depoimento do mordomo que administrava a casa de sua infância. O filme tem como protagonista Santiago Badariotti Merlo e foi realizado em dois momentos distintos. Uma primeira versão foi rodada em maio de 1992, não sendo finalizada. Em agosto de 2005 há um retorno ao material, sem novas tomadas, que é então editado. Um pequeno trecho foi montado na versão de 1992 e abre o filme. Vendo-o podemos afirmar que, em 1992, Salles quis fazer um documentário sobre Santiago, dentro de um estilo que estava em sintonia com outros filmes seus da época. No documentário de 2005/2007, Salles examina as imagens, vendo-as criticamente. Expõe oralmente as recordações de sua infância e aproveita para comentar criticamente o tipo de encenação que, em 1992, impôs ao mordomo para retratá-lo. A morte de Santiago, em 1994, acentua o tom de autocrítica: Salles perdera a oportunidade de extrair de Santiago um depoimento que revelasse a expressão mais funda de seu ser.

A idéia inicial era realizar um documentário sobre o empregado argentino, que serviu a família Moreira Salles durante décadas no Rio de Janeiro. O filme de 1992, inconcluso, possui tomadas com encenação mais clássica (do tipo construído), 
com demandas explícitas do diretor para Santiago elaborar a personagem de si próprio. Salles constantemente dá ordens, às vezes em tom autoritário, compondo a personagem com interferência bem maior que a permitida pela encenação-direta. A montagem de 2005 nos deixa ouvir as instruções em off: “agora, Santiago, você levanta, fica um pouco nessa posição, pensa na sua avó, na minha mãe"; "agora conta a história do embalsamador"; "fala de novo sem citar meu nome"; "volta para baixo"; "vamos fazer de novo" etc. O roteiro da versão original (assim como o trecho editado que nos é mostrado no início da versão de 2005) tem edição alternando a imagem de Santiago com inserts extradiegéticos que não pertenceram ao contexto do depoimento e que o ilustram em montagem alternada, em um tipo de composição narrativa muito criticada por Coutinho e pelo grupo de documentaristas que circula em torno da Videofilmes, pois nela haveria uma espécie de déficit ético, uma trapaça com o espectador, no fato de se compor o espaço com tomadas fora de ordem ou que não pertencem a seu contexto original. Por trás disso, está a ideia de que o documentário deve almejar uma espécie de grau zero da linguagem cinematográfica (que os inserts e a direção de atores negariam), se quiser ser ético. No caso específico do projeto original de Santiago, além de inserir, em montagem alternada, planos que ilustram a fala do mordomo, esses planos são compostos por uma fotografia bastante artificial (assinada por Walter Carvalho), em preto e branco, com contrastes marcados e tons fantasistas. Carvalho é um fotógrafo que até hoje trabalha bastante à vontade com iluminação de tipo esteticista. Nessa sua obra de juventude, está livre para carregar na sobreposição de camadas de luzes e efeitos no filme. Na sequência original montada, cenas de um trem de brinquedo, de um vaso de flor e de um lutador dando socos em um saco de areia são usadas como contraponto à fala de Santiago.

Ao não concluir o projeto em 1992 e ficar com as imagens paradas por mais de uma década, Salles abre espaço para retratar, além de sua evolução como 
ano I número |

dossiê

cineasta, a própria transformação estilística do documentário. Quando retorna ao material, sua consciência de cineasta já se abriu às demandas éticas do documentário moderno, particularmente em seu corte reflexivo. Embora esse contexto não estivesse por completo ausente do quadro ideológico brasileiro do inicio dos anos 1990, agora, em 2005, ocupa lugar de destaque e passa a incidir diretamente na composição estética do filme. Mas as tomadas já estão feitas e não podem ser retomadas. Santiago está morto e o tom do filme é de crítica à atuação de seu protagonista, colocando, em primeira pessoa, a culpa em um diretor insensível que não soube aproveitar as potencialidades de seu objeto por ainda estar preso ao tipo de encenação-construída. Em vez de deixar Santiago falar e desenvolver sua fascinante personalidade diante da câmera, o diretor teria, em 1992, apenas reproduzido os cacoetes de uma relação de classe. A encenação-construída de Santiago é vista como autoritária e a ela é sobreposta, pela voz over do filme, o fato de uma divisão de classes fortemente marcada no Brasil. A interação de Santiago com o sujeito-da-câmera que sustentava a câmera na época (João Moreira Salles/Walter Carvalho) não havia possibilitado o surgimento do núcleo autêntico de sua personalidade, mas sim o tipo/ personagem que Salles tentou construir de modo autoritário. Em 2005, o filme busca o núcleo autêntico da expressão de Santiago (ao qual uma encenaçãodireta teria dado acesso), na forma de uma melancolia que extravasa para a própria recordação da mansão da família e do mundo de glórias que abrigou. A experiência do eu melancólico debruça-se sobre si na narração em primeira pessoa, promovendo, pela má consciência, o resgate de uma identidade perdida, consigo mesmo e com o país dividido. Santiago, na realidade, é dois filmes em um só, o segundo debruçando-se sobre o primeiro através de um movimento reflexivo que mistura lirismo e má consciência. Salles se incrimina, e talvez isso faça com que praticamente não fale. A voz over do filme, embora em primeira pessoa, não é sua, mas de seu irmão Fernando Salles. 
O que João Moreira Salles demanda de si mesmo? Que, nas tomadas do primeiro Santiago, já tivesse a consciência crítica do documentário moderno, que então lhe faltou. Que já estivesse em sintonia com as demandas éticas da encenação-direta ou da encena-ação/afecção. Em outras palavras, que estivesse em sintonia com a franja ética que o documentário moderno exige da encenação para que a figuração de outrem seja considerada positiva. A má consciência de Salles quer que, no início dos anos 1990, já estivesse sintonizado com um tipo de documentário que chega ao cinema brasileiro no final da década, pelas mãos de Eduardo Coutinho: o documentário que explora, com uma posição recuada do sujeito-da-câmera, o tipo/personagem, fazendo girar a corda da fala. No intervalo entre o primeiro e o segundo Santiago, Salles compõe o retrato do artista quando jovem, em busca de um estilo. Nas tomadas do primeiro Santiago, encontramos uma imagem ainda em sintonia com a encenação clássica. São claras as tinturas pós-modernas da fotografia. O estilo é similar ao que vemos em América, documentário dirigido por Salles em 1989, ou ainda em Poesia é uma ou duas linhas (1989) e Dois poemas (1992), filmes com veia lírica marcada e fotografia estilizada. Na realidade, o primeiro Santiago parece estar longe de compor-se como documentário que explora camadas de personalidade através do modo de encenação direto, como depois desenvolveu Coutinho. Seria, certamente, uma exceção em sua época, mas não foi o caso. A voz crítica com que Salles narra seus esboços documentários passados acaba funcionando por acoplar-se ao discurso em primeira pessoa, que junta, à crítica do estilo, o saudosismo da infância perdida. A má consciência responde a uma espécie de purgação, necessária em 2005, dentro de um contexto de acerto de contas com um passado social que misturou a voz do ex-patrão e à direção de cena. No segundo Santiago, já convicto da ética do cinema direto, Salles centra a voz over na crítica da encenação-construída e da fotografia estilizada. A versão de 2005 é a tentativa de dar novas cores a um depoimento e um filme que foram construídos com outros parâmetros. 
Salles já lidou com alguns personagens na paleta da encenação-direta, criando belos tipos documentários (Lula/2004, Nelson Freire/2002, Rodrigo Pimentel/1999, os boleiros de Futebol/1998). O interessante é notar que, no Santiago de 2005, o esforço narrativo está em - através da voz lírica e de um trabalho de edição primoroso (capitaneado por Eduardo Escorel) - fazer emergir, da matéria-prima tomada em 1992, uma personagem que tinha potencial para ser aprumada em outra direção. Surge então um Santiago denso, nos falando do mundo fascinante de duques, duquesas e nobres cortesãos que, na história da humanidade, ele teve o cuidado de descrever em milhares de folhas guardadas num armário - personagens que pareciam ter o poder de interagir ao vivo com as figuras da casa em que serviu. Santiago, no novo filme, luta para fazer sua fala sobreviver, através da direção que antes abafava sua personalidade. Através da culpa, e da recordação, a nova edição consegue deslocar o movimento original de limitar a ação de Santiago no intervalo restrito de personagem pré-imaginada. Em seu lugar, numa posição que constrói pela edição o recuo do sujeito-da-câmera, abre-se um espaço máximo para a expressão da fala de Santiago, conduzida com sensibilidade pela locução em primeira pessoa. A forma típica de direção da encenação-construída mostra, em 2005, seus limites como proposta fora de época. Nesse caso, o clamor pelo que se perdeu e o remorso pela direção canhestra nos dão a clara medida da interação entre valores éticos e modo de encenação.

Em Jogo de cena (2007), Eduardo Coutinho confronta diretamente a questão da encenação. O filme evidencia a presença do tema no documentário contemporâneo brasileiro. A ideia original do diretor era tomar depoimentos de mulheres anônimas sobre suas histórias de vida, contrapondo-os aos mesmos depoimentos encenados por atrizes. Pessoas comuns dariam depoimentos e atrizes os encenariam, dentro do estilo que caracteriza os últimos filmes de Coutinho: imagens frontais, em primeiro plano, com falas contínuas que realçam a personalidade por meio da composição da expressão na face. A 
ideia inicial de contraposição e mistura de dois modos de encenar (pessoas comuns encenando em documentários e atores profissionais encenando no modo em que encenam filmes de ficção) evolui para variáveis mais complexas. Passa a envolver treze mulheres que atuam no filme com formas distintas de encenação face à câmera. Dentro dos parâmetros de encenação que analisamos neste ensaio, podemos delimitar: a) sete pessoas comuns (que vou chamar de personagens) expressando seus afetos em depoimentos frontais, ${ }^{5}$ dentro da forma da encenação-direta do tipo encena-afecção; b) três atrizes estrelas (Marília Pêra, Fernanda Torres e Andréa Beltrão), rostos famosos na televisão, no cinema e no teatro brasileiros, interpretando três depoimentos das outras sete personagens no modo encenação-construído de atores profissionais, também em depoimentos frontais; c) três atrizes pouco conhecidas (o público brasileiro não chega as distingui-las como atrizes) interpretando, no modo-construído, dois depoimentos de personagens que aparecem com corpo e fala no filme. Além disso, há uma personagem (portanto uma oitava personagem) que tem sua fala interpretada por uma das três atrizes desconhecidas, mas seu corpo não aparece.

Jogo de cena nos remete, indiretamente, a quatro modalidades de encenação, embora interaja com duas delas, quais sejam: a) encenar a vida de outrem, personagem real, ao qual tem-se acesso vendo seu corpo e ouvindo sua fala em um vídeo previamente gravado; b) encenar a si mesmo, falando de um acontecimento sofrido por seu próprio corpo no passado. A terceira modalidade de encenação, encenar uma personagem fictícia, passa ao largo da experiência das atrizes do filme, apesar de permanecer constantemente como referência no horizonte. Há uma quarta modalidade de encenação da qual Coutinho sempre fugiu, mas que exerce sua influência no filme: a representação, no modo da encena-afecção, de personalidade conhecida socialmente e presente na mídia 
audiovisual. Nesse caso, o cineasta explora o rosto conhecido da personalidade em primeiro plano, trabalhando, de modo inédito, o afeto fisionômico em situação cotidiana. Coutinho nega essa modalidade, preferindo trabalhar com rostos anônimos. Especificamente em Jogo de cena, explora a expressão de atrizes estrelas, mas numa modalidade diferencial. O trabalho com a imagem do rosto da personalidade estrela (seja política ou artística) é uma tendência muito em voga no documentário contemporâneo (como paradigma, podemos citar Errol Morris em The Fog of War: Eleven Lessons from the Life of Robert S. McNamara, de 2003). Foi explorada inicialmente por diretores que, nos anos 1960, filmaram sob a influência da estilística do novo cinema direto (Don't Look Back,- de Pennebacker, 1967; ou, no Brasil, Bethânia bem de perto, a propósito de um show,- de Bressane e Escorel, 1966). Em Meet Marlon Brando (Maysles, 1965) ou Jane (Drew, 1962), temos a câmera do cinema direto trabalhando com a encenação-direta de atores (Marlon Brando e Jane Fonda), num estilo por inteiro distinto daquele em que atuam Marília Pêra, Fernanda Torres e Andréa Beltrão em Jogo de cena. No filme de Coutinho, o desafio é que as atrizes construam tipos com base em personagens reais, no modo da encenação-construída. Em Meet Marlon Brando ou Jane, a graça está em ver estrelas encenando para a câmera no modo direto.

Em Jogo de cena, os depoimentos das atrizes e das personagens são sempre frontais, com a câmera fixa e a plateia de um teatro ao fundo. Com exceção dos rostos conhecidos das três atrizes estrelas, o estatuto de quem fala não é distinguível em um primeiro momento. A narrativa não aponta explicitamente quem é quem (não há letreiros nem voz over para identificação), apesar de dar algumas dicas na própria montagem: dois depoimentos similares são falados por pessoas distintas, ou discursos retomam fatos já mencionados por outro corpo-personagem. Também são utilizadas frases que caracterizam o estatuto de atriz de quem fala. Neste último caso, uma das atrizes desconhecidas, Débora Almeida, termina a bela interpretação da personagem Maria Nilsa 
Gonçalves dos Santos com a frase "foi isso o que ela disse", o que revela o tipo de encenação até então oculto. Não é mais a migrante negra de Minas Gerais que narra suas desventuras na grande metrópole paulistana, mas uma atriz, ligada ao movimento negro carioca, com carreira ainda de pouca expressão, que a está interpretando. Outras sobreposições são cometidas pela narrativa, algumas não esclarecidas ou esclarecidas tardiamente, como no caso de Lana Guelero (figurante ocasional de telenovelas) interpretando o relato de vida de Claudiléa Cerqueira de Lemos, personagem que nos conta como enfrentou a perda do filho. Ao ouvirmos o primeiro relato, tendemos a acreditar que Lana Guelero fala de sua própria vida e a narrativa nada faz para nos esclarecer. Quando, ao final do filme (trata-se do último depoimento), encontramos novamente a mesma história (embora montada de modo distinto), progressivamente nos damos conta do logro, do estatuto construído da primeira interpretação e do estatuto direto da fala real de Claudiléa, que agora ouvimos. Retrospectivamente, transforma-se a relação espectatorial ante as expressões de Lana Guelero. Para o espectador não está claro qual das duas é a verdadeira mãe que perdeu o filho e qual é a atriz. A composição narrativa oscila em um tom de "falso documentário", mas não é a implementação desse efeito que a norteia. Trata-se, antes, de um autor (Coutinho) no limite do estilo que criou, explorando de modo maneirista os paradoxos de sua obra.

Nos depoimentos das sete personagens que falam efetivamente para a câmera no filme estamos próximos do estilo desenvolvido por Eduardo Coutinho em sua maturidade, principalmente a partir de Santo forte (1999). Estilo marcado pela busca de personalidades anônimas no universo popular, lapidadas em seguida pela edição. Depois de diversos longas nesta linha (Babilônia 2000, 2000, Edifício Master, 2002, Peões, 2004, O fim e o princípío, 2005), o diretor parece ter sentido o esgotamento da forma e Jogo de cena é o momento em que se volta sobre sua obra e seu estilo. É um filme que penetra fundo no universo feminino ao recolher oito intensos depoimentos de vida e fazer com que outras 
ano I número |

dossiê

seis mulheres se debrucem sobre eles na forma de uma encenação. O resultado do contato vida/encenação é intenso. Jogo de cena é, antes de tudo, um filme carregado de emoção, com lágrimas constantes compondo expressões de forte carga afetiva. As atrizes sentem o universo forte no qual estão montadas e interagem ativamente com ele. Para as atrizes estrelas, o jogo de interpretação se desloca. A espessura do trabalho de construção da personagem cresce, toma forma própria e assusta. Os filmes de Coutinho são centrados em dois fatores, para obter o resultado que apresentam: a lapidação, na edição, do material bruto e o dispositivo montado para colheita dos depoimentos. Em seus últimos longas, o diretor repete um tipo de preparação de cena para colher os depoimentos. Jogo de cena é o resultado indireto desse trabalho. Como se compõe essa preparação? O ponto diferencial está em que Coutinho não tem contato prévio com as personagens antes das tomadas do filme propriamente: todos os contatos que preparam a filmagem dos depoimentos são feitos por assistentes de direção e pela equipe. Os assistentes filmam as futuras personagens em testes mostrados a Coutinho, que seleciona então os escolhidos. As personagens só travam contato visual com o diretor no dia da filmagem.

No caso de Jogo de cena, para a seleção das personagens, foi colocado anúncio em jornal com os dizeres: "se você é mulher com mais de 18 anos, moradora do Rio de Janeiro, tem histórias pra contar e quer participar de um teste para um filme documentário, procure-nos. Ligue a partir de 17 de abril (10 às 18hs) para [...]". O primeiro plano do filme mostra em close esse anúncio, deixando claro, para o espectador, o dispositivo utilizado para a seleção das personagens. Todos os contatos diretos para escolher as personagens do filme foram feitos por auxiliares, sob a supervisão distante de Coutinho. As três atrizes não profissionais ensaiaram sua encenação com assistentes. As atrizes estrelas receberam vídeos com os depoimentos das personagens na íntegra, ou já montados, para ensaiarem em casa. Com as estrelas, nenhum tipo de direção de atores foi exercido por Coutinho, e elas trabalharam livremente 
(e solitariamente) na criação de suas personagens. Receberam apenas a sugestão de que não deveriam "imitar" ou "julgar" para compor os tipos. Além do anúncio em jornal, também foram escolhidas personagens e atrizes amadoras em contatos pessoais, ou por mero acaso. Outro ponto central para se compreender a construção da cena é o fato de que as tomadas foram concentradas em dois momentos distintos. A gravação com as personagens (mulheres comuns) ocorreu em junho de 2006 no Teatro Glauce Rocha, Rio de Janeiro, e as gravações com as atrizes interpretando os depoimentos ocorreram três meses depois, em setembro, no mesmo local. O esquema de gravar primeiro com as personagens e depois com atrizes permitiu a composição da encenaçãoconstruída das atrizes, dando-lhes acesso às imagens-câmera do corpo, da voz e da expressão das personagens. A composição da encenação a partir da imagem falante de corpos (e não da escrita da personagem) é uma das singularidades das interpretações do filme.

Nos modos de encenação de Jogo de cena, o fato de trabalharem diretamente com a imagem do corpo, fala e face da personagem que representam parece ter desarmado as atrizes profissionais. A reação ao dispositivo montado para detonar a encenação ficcional foi diversa. Marilia Pêra, prima-dona da cena brasileira, mantém-se altiva e opta por uma interpretação minimalista como forma de sair ilesa do desafio. Sua personagem (Sarita Brumer) transborda intensidade por todos os poros, o que certamente dificulta a composição. Pêra atua com o freio de mão puxado, expressões contidas, mas mantém a essência do tipo que está representando pela composição de traços e expressões-chaves. A distância fria mostra profissionalismo e o resultado, se não deslumbra, também não é comprometido. Andréa Beltrão prefere grudar-se à expressão da personagem e tenta seguir o avanço fisionômico de seu tipo (Gisele Alves Moura) como se estivesse trotando a seu lado, como se fosse possível tocar flauta em cima de uma serpente. Gisele é uma personagem bem mais contida que Sarita, mas com um olhar de corte intenso que beira o esquizofrênico. Beltrão fica 
longe de conseguir reproduzir a intensidade contida da personagem, próxima ao delírio frio. A decalagem mostra um trabalho de interpretação aplicado, mas superficial. Fernanda Torres, atriz que busca naturalmente a intensidade, não poderia deixar o desafio passar em branco. Compra o embate com o corpo da personagem, quer enfrentá-lo diretamente e acaba dando-se mal. Sua personagem (Aleta Gomes Vieira) também é do tipo contido, narrando uma história de gravidez precoce que a impediu de aproveitar a vida como desejava. Aleta tem um olhar marcante que parece perfurar a câmera, mas as expressões, em si mesmas, pouco se alternam durante seu depoimento. Fernanda sente o desafio que é criar uma personagem a partir de corpo e voz reais e parte para um enfrentamento meio às cegas. A luta parece ser desigual e, no meio do caminho, ela se dá conta de que não está indo a lugar nenhum. Com efeito, como repetir, através de si, o corpo e a expressão natural de outrem, ainda que modalizados pela presença da câmera na forma da encenação-direta. A atriz sente que está em território desconhecido e que seu esforço (ele claramente existe) está sendo em vão. Em determinado momento, entrega os pontos, voltase para Coutinho e começa a falar da própria dificuldade que está tendo para encenar na modalidade proposta. Adiante, Fernanda ainda tenta retomar a encenação da vida de Aleta, mas os resultados são sempre achatados e pouco elaborados, distantes do denso trabalho de atriz que possui. Em determinado momento, seguindo sugestão do diretor, não explicitada para o espectador, passa a narrar um episódio de sua vida pessoal, aparentemente misturando algo que ouviu e viveu (Andréa Beltrão, em um breve trecho, também interpreta a si mesma e sua vida no filme). O tom muda e reencontramos a Fernanda que conhecemos. Sente-se que lhe foi tirado um peso dos ombros, ela volta a ter firmeza de atriz. Fica bem à vontade, com total domínio de si e da encenação que conduz. Passa a girar expressões faciais na velocidade costumeira, seguindo a experiência de vida (própria) que interpreta. 
As atrizes amadoras, em Jogo de cena, aparentemente têm mais facilidade em enfrentar o desafio da encenação-construída de personagens reais. Contaram com certo auxílio da produção do filme para trabalhar o material (depoimentos gravados), fornecido para a composição dos tipos. Entram com tal intensidade na pele das personagens que é difícil para o espectador distingui-las. Não possuem a figura fisionômica já cristalizada das estrelas, que imediatamente provoca um padrão de recepção mais próximo da encenaçãoconstruída ficcional. Com as atrizes amadoras, mesmo retrospectivamente (pois, em um primeiro momento, a narrativa faz com que acreditemos ver uma personagem atuando diretamente), nota-se que estão à vontade para interpretar uma personagem real. Não possuem a experiência nem o talento das estrelas, mas, estranhamente, neste tipo de proposta, saem-se nitidamente melhor no trabalho de interpretação. Caminham facilmente para o núcleo da expressão da personalidade da personagem real, numa rota direta em que as estrelas, oscilando, não conseguem vislumbrar passagem. Das quatro atrizes amadoras que encenam personagens, Mary Sheila (que abre o filme) é a que está menos à vontade. Encena a vida de Jeckie Brown, sua colega do grupo teatral Nós do Morro, que surge mais tarde no filme dando seu depoimento. Parece estar muito próxima da personagem e a proximidade a impede de ficar à vontade para criar. A interpretação está dura. A ação de expressar-se pede compreensão ao espectador para a missão que ambas encarnam e à qual devese solidariedade. Débora Almeida entra firme na personagem de Maria Nilza Gonçalves dos Santos. Age naturalmente, de modo que temos a impressão de que sempre viveu naquela pele. Mas é atriz e sua atuação, na proximidade, é magnífica. Podemos dizer o mesmo de Lana Guelero, com a diferença que a distância é um pouco maior. Sua interpretação possui a frieza necessária para incorporar o drama da morte de um filho, na medida contida em que é narrada pela personagem Claudiléa Cerqueira de Lemos. Lana é atriz amadora, atua como figurante em novelas, mas cresce no papel e nos fornece a atuação impecável de uma personagem densa. Se sua personagem estivesse composta 
em uma peça de teatro e seu trabalho fosse um trabalho de atriz, traria para si consagração arrebatadora em termos de atuação.

As oito personagens do filme são compostas a partir das personalidades de mulheres anônimas, populares ou de classe média. Todas possuem personalidades fortes, dentro do estilo que Eduardo Coutinho descobriu e fixou nos anos 2000 e com o qual já nos apresentou outras personagens memoráveis. Gisele Alves Moura e Aleta Gomes Vieira (ambas personagens interpretadas a posteriori pelas atrizes estrelas Andréa Beltrão e Fernanda Torres) fazem o tipo contido, com olhar for te e interiorizado. Coutinho deve ter estabelecido alguma relação entre o tipo semelhante que possuem e o campo para a atuação das atrizes profissionais. Sarita Houli Brumer e Maria de Fátima Barbosa exalam personalidade mais espaçosa, fazendo valer sua expansividade nas entrevistas. Sarita, inclusive, pede para retornar, completa o depoimento com uma canção e recebe a honra de encerrar o filme cantando uma canção infantil com a voz de Marília Pêra (que a interpreta) ao fundo, em off. Sarita e Maria de Fátima possuem tipos marcantes e sabem fazer valer sua história de vida pessoal por meio da expressão da personalidade em gestos e fisionomia. Claudiléa Cerqueira de Lemos é voltada para si, contida, possui um tipo mais depressivo, com olhar calmo e receptivo. Nos momentos agudos de seu depoimento, falando da perda do filho e da dívida de Deus consigo, sabe mostrar-se afirmativa e segura. De Maria Nilza Gonçalves dos Santos não vemos o corpo e nem ouvimos a fala. Ela aparece nos extras do DVD, mas não compõe a narrativa fílmica propriamente. Sua história de vida é narrada pelo filme na interpretação primorosa de Débora Almeida. A atriz sente-se completamente à vontade com o papel e consegue incorporar o tom moleque da personagem, no relato impagável da "trepadinha de galo" com um cobrador de ônibus no dia em que chega São Paulo, após a qual acaba gerando involuntariamente seu filho. Nessas personagens está a carne do filme propriamente, o material humano que as atrizes potencializam em direções diversas, e sobre o qual filme e espectadores se debruçam. Jogo de 
cena é, antes de tudo, um filme de mulheres. Um filme que traz a representação dos traços da personalidade for te da mulher brasileira, flexionados pela questão estilística que forma o “jogo de cena”. Pelo catalisador "personagem”, nos são relatados pequenos dramas cotidianos e grandes encruzilhadas de vida, que tocam fundo a alma feminina. Certamente, as personagens foram selecionadas (oitenta e três depoimentos foram gravados inicialmente, a partir do anúncio de jornal) e o filme não se propõe a fornecer um quadro estatístico da situação da mulher no Brasil. No entanto, a forma de exposição que constrói compõe mosaico significativo.

Jogo de cena é um filme de depoimentos e personagens que aponta para um momento de crise do próprio estilo que encarna. O delinear dos tipos, no formato caro a Coutinho, é modulado por uma espécie de maneirismo, momento em que procedimentos cristalizados se voltam sobre si e apontam para seu esgotamento. Não basta mais ao documentário descobrir personagens, tipos humanos, em cidadãos comuns e imortalizá-los. Coutinho vai além, sente necessidade de tensionar suas estratégias e o dispositivo montado. Adentra um outro lado da moeda que atrai sobremaneira a consciência contemporânea. As personagens-personalidades que o documentário apresenta ao espectador como descobertas meio ao acaso estão na beirada de serem construções livres do próprio diretor. O olho do rodamoinho da personalidade, que parece surgir do nada, é, em Jogo de cena, canalizado pelo dispositivo que prepara a tomada, mecanismo que dá substância à fala que a entrevista extrai para depois lustrá-la pela montagem na edição. Jogo de cena satisfaz a boa consciência contemporânea ao dizer que há trabalho e construção na espontaneidade das personagens que, nos últimos dez anos, vêm pipocando pelos filmes de Coutinho. Esse é o núcleo em que a ética atual do documentário é construída, e Coutinho vai bater ponto no quesito, mostrando sua sintonia com a demanda. No estilo que Coutinho desenvolveu, o momento reflexivo ocorre quando a encenação-direta é desconstruída e 
ano I número |

dossiê

sobreposta, numa mistura, a diversas modalidades de encenação-construída. A encenação- direta, no modo que predomina em suas obras a partir de Santo forte, agora é integrada a formas extremas da encenação-construída, já para além do campo documentário. O trabalho com a encenação-construída de atrizes estrelas, coisa rara na história do documentário, é feito aqui por um diretor que possui larga carreira autoral no campo. Embora não seja o único a enfrentar o desafio de trabalhar com estrelas em documentários, Coutinho certamente é uma exceção nesse quesito. Diretores de documentário não sabem nem se interessam em trabalhar com estrelas, ainda que documentários tenham, historicamente, amplamente lidado com atores amadores ou pessoas comuns encenando personagens que não são eles próprios.

Neste ensaio propusemos um método analítico para a narrativa documentária, centrado na relação entre o sujeito que sustenta a câmera na tomada e o mundo que a ele se oferece, abrindo-se pelo seu corpo (sujeitoda-câmera) ao espectador. Denominamos de "encenação" essa relação entre o mundo (com suas pessoas agindo) e o sujeito-da-câmera. A mise-en-scène designa o modo pelo qual a encenação é disposta na tomada, levando-se em conta os diversos aspectos materiais que compõem a cena em que se insere e sua futura disposição narrativa (em planos). Nesse sentido, olhando para história do documentário (como narrativa com imagens e sons, formados predominante de tomadas), podemos notar duas variantes estruturais na ação das pessoas na tomada. Denominamos essas variantes de encenação-construída (quando a ação para a câmera é planejada ou orientada anteriormente pelo sujeitoda-câmera) e encenação-direta (quando a ação para a câmera está solta no mundo, ocorrendo sem uma flexibilização marcada pelo sujeito-da-câmera). Esta última pode ainda se distinguir em ação, quando movimento, ou em afecção, quando expressão do sujeito que se oferece para a câmera. Tentamos aqui distinguir modalidades pelas quais o sujeito-da-câmera pode orientar ou flexibilizar a ação na tomada, em particular na obra dos documentaristas João Moreira Salles e Eduardo Coutinho. 


\section{Referências bibliográficas:}

AITKEN, Ian. Realist Film Theory and Cinema: the nineteenth-century lukácsian and intuitionist realist traditions. Manchester: Manchester University Press, 2006.

AUMONT, Jacques. Le Cinéma et la Mise-en-scène. Paris: Armand Colin, 2006.

BORDWELL, David. Figuras traçadas na luz. Campinas, SP: Papirus, 2005.

CAVALCANTI, Alberto. Filme e realidade. Rio de Janeiro: Casa do Estudante, 1957.

LINS, Consuelo. O documentário de Eduardo Coutinho: televisão, cinema e vídeo. Rio de Janeiro: Zahar, 2004.

MERLEAU-PONTY, Maurice. Phénoménologie de la Perception. Paris: Gallimard, 1945.

MOURLET, Michel. Sur un Art Ignoré: la mise-en-scène comme langage. Paris: Ramsay, 2008.

NICHOLS, Bill. Introdução ao documentário. Campinas, SP: Papirus, 2005.

. Representing Reality: issues and concepts in documentary. Indianapolis: Indiana University Press, 1991.

RAMOS, Fernão Pessoa. A imagem-câmera. Campinas, SP: Papirus, 2012.

SOBCHACK, Vivian. "Inscrevendo o espaço ético: dez proposições sobre morte, representação e documentário". In: RAMOS, Fernão Pessoa (Org.). Teoria contemporânea do cinema: documentário e narratividade ficcional. São Paulo: Ed. Senac, 2004

. The Address of the Eye: a phenomenology of film experience. Princeton: Princeton University Press, 1992.

STANISLAVSKI, Constantin. A preparação do ator. Rio de Janeiro: Civilização Brasileira, 2011. 